\title{
陆相水下火山喷发作用及其对优质烃源岩形成的 影响：以松辽盆地徐家围子断陷营城组为例
}

单玄龙 ${ }^{(1)}$ ，李吉炎 ${ }^{(1 *}$ ，陈树民 ${ }^{(2)}$ ，再清昌 ${ }^{(2)}$, 陈贵标 ${ }^{(1)}$, 刘超 ${ }^{(1)}$

(1) 吉林大学地球科学学院, 长春 130061 ;

(2) 中国石油大庆油田有限责任公司勘探开发研究院, 大庆 163712

* 联系人, E-mail: lijiyan3@163.com

收稿日期: 2013-11-25; 接受日期: 2014-03-27; 网络版发表日期: 2014-11-14

国家重点基础研究发展计划项目(编号: 2009CB219306)、东北亚生物演化与环境教育部重点实验室项目、吉林大学“211”工程三期建设项 目和 2009 年教育部基本科研业务经费项目(吉林大学创新团队发展计划)资助

\begin{abstract}
摘要通过对松辽盆地徐家围子断陷营城组火山岩岩芯和薄片的观察，结合地震、测 井资料, 岩芯样品地球化学的测试数据和古地理背景, 认为研究区内存在水下喷发作用 形成的火山岩. 松辽盆地徐家围子地区水下喷发火山岩的识别标志为沉凝灰岩与黑色 泥岩互层、双层珍珠岩夹无斑或少斑流纹岩、膨润土和氧化系数 $\left(\mathrm{Fe}^{3+} / \mathrm{Fe}^{2+}\right)$. 岩石类型有 火山角砾岩、熔结角砾岩、珍珠岩、流纹岩、凝灰岩和沉凝灰岩, 岩相以爆发相和喷溢 相为主，水下喷发分布范围主要集中在汪家屯、升平、徐西、徐中和徐东等地区，以徐 深 1 井区最为典型. 研究区营城组火山岩上覆泥岩有机质丰度均值大于 $2.0 \%$, 为优质烃 源岩, 分析认为陆相水下喷发火山作用不仅为湖盆提供了丰富的矿物质和能量, 使水体 中有机质的含量增高，而且水体分异作用的产生，为有机质的保存提供了良好的还原环 境, 有利于优质烃源岩的形成, 并据此建立了水下喷发与优质烃源岩形成的模式.
\end{abstract}

关键词

陆相水下火山喷发

识别标志

优质烃源岩

营城组

徐家围子断陷
近年来, 火山岩油气已经成为国内外油气勘探 的重要领域, 火山作用与油气形成的关系也正在成 为研究热点. 前人在火山岩的岩性、岩相、储层及发 育背景等方面做了大量的研究和探讨. 火山岩喷发 环境是火山岩油气藏发育的关键因素之一. Lafrance 等(2000)对加拿大魁北克省阿比提比绿岩带的水下 喷发复合式火山进行了剖析，描述了水下喷发基性、 中性和酸性火山岩的产状及分布, 模拟了 Normetal 火山复合体的演化过程. Parfitt 等(2002)对比分析了
夏威夷基拉韦厄峰火山水下和陆上喷发形态和爆发 类型. Embley 等(2006)直接观测了位于北马里亚纳联 邦的罗塔岛西北部 $60 \mathrm{~km}$ 处水下火山喷发的过程, 为 地质学工作者提供了对水下喷发火山特征的更直观 认识. Palinkas 等(2008)对克罗地亚西北部水下玄武 质熔岩复合体火山岩岩相进行了分析, 建立了水下 喷发及成藏过程模式. Seghedi(2011)对罗马尼亚 Sirinia 盆地二叠纪水下和陆上火山喷发形成火山岩 进行了系统的研究, 确定了 Sirinia 盆地内部水下和

中文引用格式: 单玄龙, 李吉炎, 陈树民, 等. 2014. 陆相水下火山喷发作用及其对优质烃源岩形成的影响：以松辽盆地徐家围子断陷营城组为例. 中国科 学: 地球科学, 44: 2637-2644

英文引用格式: Shan X L, Li J Y, Chen S M, et al. 2013. Subaquatic volcanic eruptions in continental facies and their influence on high quality source rocks shown by the volcanic rocks of a faulted depression in Northeast China. Science China: Earth Sciences, 56: 1926-1933, doi: 10.1007/s11430-013-4657-7 
陆上喷发火山岩的分布范围, 并对野外出露的岩石 进行了详细的描述. 此外, 日本学者山岸宏光 (Yamaqishi, 1990)从 20 世纪 90 年代开始专门研究水 下火山活动, 整理了大量关于水下火山喷发的文章 及图件, 并编写了有关水下火山岩层序及水下火山 岩用语解说等图书. 随着国外学者对水下喷发火山 观测和实验研究的不断深入, 水下环境对火山岩油 气藏发育的影响引起了国内的关注. 本文以松辽盆 地营城组火山岩为例, 利用岩芯、测井、地震和地球 化学等资料, 探讨陆相水下环境火山喷发的识别标 志, 确定松辽盆地徐家围子断陷陆相水下喷发火山 岩的分布范围, 并建立了陆相水下喷发作用及其对 优质烃源岩形成的模式.

\section{1 松辽盆地徐家围子断陷营城组分布及演 化特征}

松辽盆地徐家围子营城组分布范围广泛, 形成 于断陷后期，沉积时期湖盆发育，后期地壳抬升，水 域扩大, 水体变浅. 伴随着强烈的多期次火山喷发作 用, 每一期火山喷发的间歇期都接受火山沉积岩或 陆源碎屑岩的沉积, 形成了一套火山岩-陆源碎屑夹 泥或煤的沉积建造.

徐家围子断陷营城组纵向序列特征, 营一段为 大面积分布的火山岩, 以中酸性流纹岩和流纹质凝 灰岩为特征, 厚度为 $20 \sim 650 \mathrm{~m}$. 营二段开始沉积格 局明显改变, 仅分布于宋站南部-榆树林西部的狭小 凹陷内, 湖泊相区主要分布在断陷近中央部位, 两侧 均有辫状平原扇和辫状三角州分布, 厚度为 92 640 m. 营二段发育半深-深湖相泥岩, 是徐家围子地区断陷 期重要的优质烃源岩之一. 营三段火山岩分布范围 较小, 以玄武岩和流纹质凝灰角砾岩为主, 厚度为 85 347 m. 营四段沉积范围扩大, 在整个古中央隆起 以东地区都有沉积, 以湖泊沉积为主, 边缘局部有辫 状平原扇沉积, 厚度为 0 400 m(王玲等, 2009).

徐家围子断陷营城组平面分布特征, 火山喷发 区以火山通道为中心, 向四周发育不同的岩性和岩 相. 过渡区以火山碎屑岩和沉积岩互层为特征, 是火 山喷发区与沉积区的过渡相区, 包括河流相、沼泽 相、滨浅湖相和火山碎屑沉积的空落相、火山泥石流 相、火山碎屑冲积扇相和火山碎屑河流相. 沉积区发 育河流相、滨浅湖相和深湖相, 岩性由砂砾岩、砂岩
和粉砂岩夹泥岩组成. 整体上看, 松辽盆地徐家围子 断陷营城组火山岩在的岩性和岩相在纵向上交替反 复, 在横向上杂乱交错(陈建文等, 2000).

\section{2 松辽盆地徐家围子营城组陆相水下喷发 的典型标志}

通过对徐家围子断陷营城组火山岩岩性、岩相、 地震及测井特征的研究, 结合国内外对水下喷发火 山岩的研究成果, 认为研究区水下喷发火山岩的典 型标志为沉凝灰岩与泥岩粉砂互层、双层珍珠岩夹无 斑或少斑流纹岩、膨润土层和氧化系数 $\left(\mathrm{Fe}^{3+} / \mathrm{Fe}^{2+}\right)$ 等. 另外, 酸性的水下熔岩经重结晶作用后能形成显微 花岗变晶或显微角岩结构的石英-长石集合体. 水下 熔岩球粒一般较小, 通常为 $0.1 \sim 1 \mathrm{~mm}$, 放射状构造 很不明显. 水下火山岩浆喷发所带来的热驱动力和 火山构造的发育是形成最活跃的热流循环系统的基 本条件, 也造成了火山岩自变质作用有力的环境, 因 此水下火山喷发形成的火山岩变质现象突出(姜福芝 和王玉往, 2005), 水体较深的水下喷发火山岩还具有 角砾自碎的结构(图 1(a)和(b)).

\section{1 沉凝灰岩与暗色泥岩互层}

沉凝灰岩与暗色泥岩互层(图 1(c)和(d)) 主要是 火山碎屑降落在湖盆中缓慢沉积形成的, 其广泛分 布于水下喷发火山岩中. 岩相为爆发相夹火山沉积 相. XS1 4 井 3584 3655 m 段(图 2)GR 曲线形态为高 振幅齿形, 该井段有煤岩夹层, 煤的导电性较好, 放 射性物质含量高, RD 曲线在煤层出现峰值 $240 \Omega \mathrm{m}$, 该井段振幅接近与一般沉积岩的特征, 振动幅度大 于其他火山岩.

\section{2 双层珍珠岩夹无斑或少斑流纹岩}

珍珠岩是火山玻璃的一种，一般认为火山玻璃 是酸性岩浆喷溢到骤冷的环境中或侵入到冷围岩中 形成的, 而珍珠岩除了上述条件外还需要大量的水 分子加入(高恩忆, 1986; 胡志宪, 1987). 当酸性岩浆 喷出地表后, 在地表流动状态时的温度约为 $800^{\circ} \mathrm{C}$ 以 上, 由于岩浆温度与地表温度相差悬殊, 溢出岩浆的 外部由于温度迅速下降产生塑状玻璃并形成较长的 裂缝, 随着温度进一步降低, 垂直于长断裂的短裂缝 出现，再经过水化作用，玻璃质的熔体被分割成圆形 


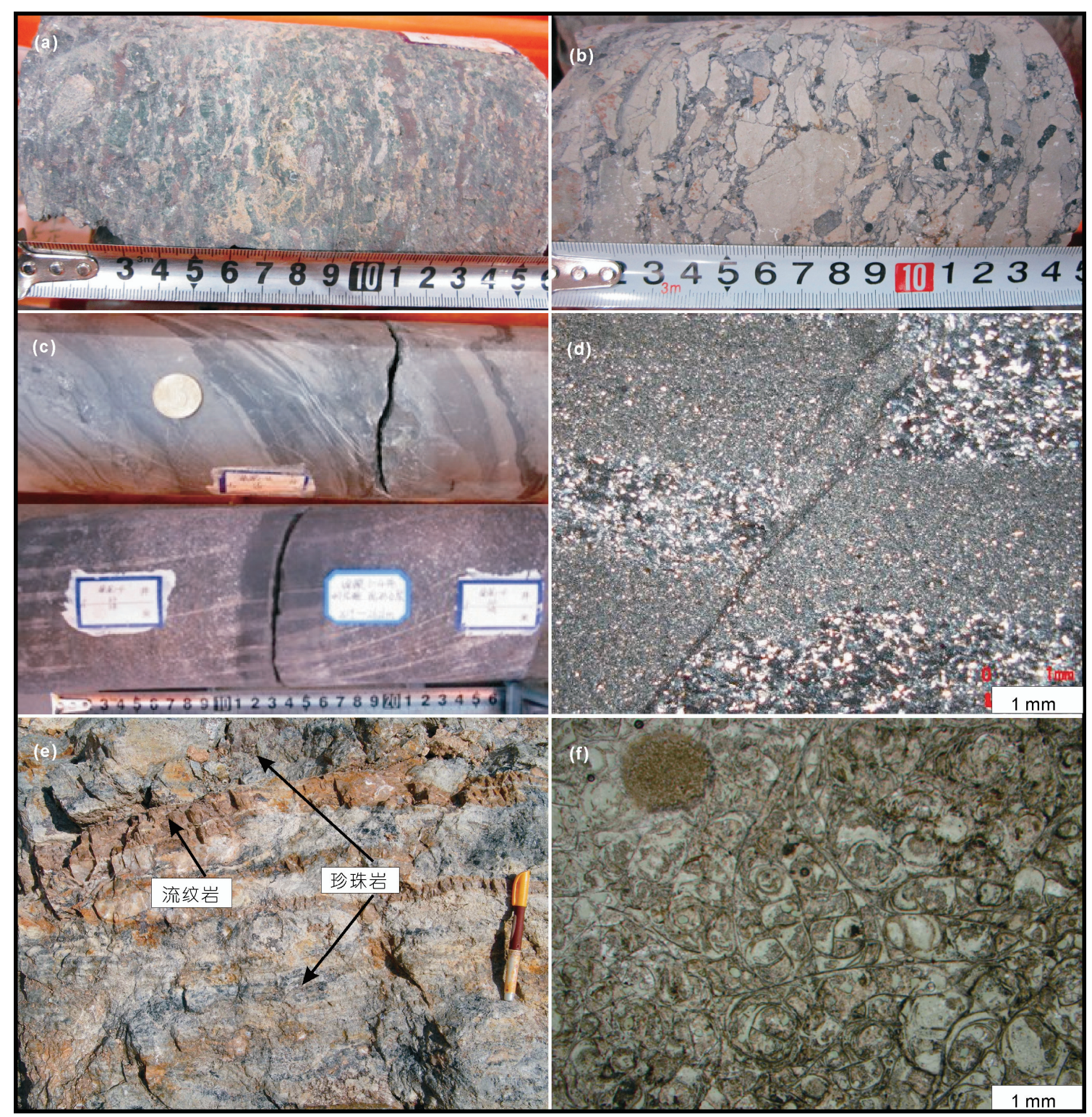

图 1 典型样品照片

(a) 升深 2-12, 3352.8 m, 强烈蚀变; (b) 徐深 21-1, $3834 \mathrm{~m}$, 自碎角砾; (c) XS1 4 井, 沉凝灰岩与黑色泥岩互层, 厚 $6.42 \mathrm{~m}$; (d) 五台大屯东山地 区, 晶屑凝灰岩、沉凝灰岩与泥岩互层; (e) 九台煤矿, 双层珍珠岩夹无斑或少斑流纹岩; (f) 升深更 2, 珍珠岩, 珍珠结构, $3004.64 \mathrm{~m}$

珍珠结构的集合体，形成珍珠岩(Davis 和 McPhie, 1996). 而岩浆内部由于不能及时降温，在相对缓慢 的冷却条件下形成无斑或少斑流纹岩。在湖盆或地 表水丰富的环境中形成的珍珠岩，由于其顶部和底 部均有骤冷现象, 一般形成上下两层, 中部为无斑或 稀斑流纹岩(图 1(e),(f); 图 3), 如果不具备这种环境, 则只能在岩流顶部形成一层珍珠岩矿层(张耀夫等, 1990).
珍珠岩的岩相常见有爆发相热碎屑流亚相(XS21$1, \mathrm{~W} 905, \mathrm{SS} 2-12$ 和 XS9), 侵出相(SSG2 和 XS5)中带 亚相、内带亚相. 珍珠岩的测井形态显示为高伽玛和 低阻的特征, 与相近流纹岩相比, 珍珠岩 $G R$ 略低与 流纹岩, 以 XS5 为例(图 2), 3859 3886 $\mathrm{m}$ 井段珍珠岩 $G R$ 均值为 140 API, 3886 3908 $\mathrm{m}$ 井段流纹岩 $G R$ 均 值为 173 API. 流纹岩 $R D$ 值一般高于 $40 \Omega \cdot \mathrm{m}$, 而珍 珠岩 $R D$ 值一般小于 $40 \Omega \cdot \mathrm{m}$, 该特征在本研究中表现 


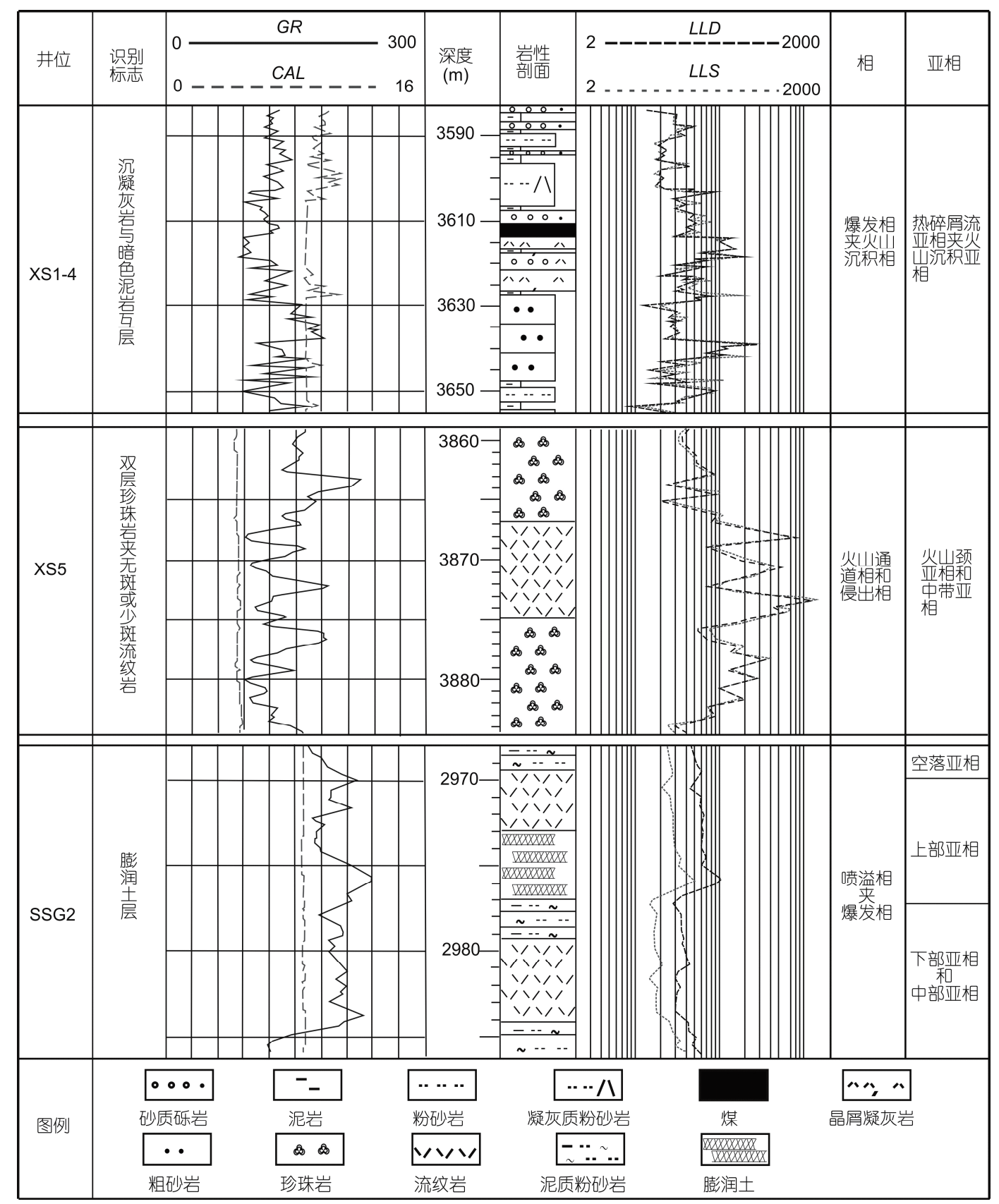

图 2 水下喷发火山岩识别标志综合柱状图

明显, XS2, W905, SS2-12, XS21-1, XS401 和 XS3 中珍 珠岩 $R D$ 值均小于 40 , 各别井段有 $R D$ 高阻现象, 一般 是由于裂隙含气层或局部脱玻化重结晶作用引起的.

\section{3 膨润土层}

膨润土层, 主要为玻璃质火山物质空落于碱性 湖盆中淬火水解沉积或酸性玻璃质熔岩脱玻水解形
成的. 水下形成的膨润土层主要为爆发相玻璃质火 山碎屑或火山灰直接入湖形成的. 从规模上看, 水下 形成的膨润土层范围最大，而喷溢相或侵出相酸性 玻璃质熔岩蚀变而成的膨润土层范围主要集中于火 山口附近，范围较小．从蚀变程度上看，水下形成的 膨润土层纯度较高, 原岩几乎完全蚀变为膨润土, 而 酸性玻璃质熔岩蚀变作用相对消弱，岩体内膨润土 


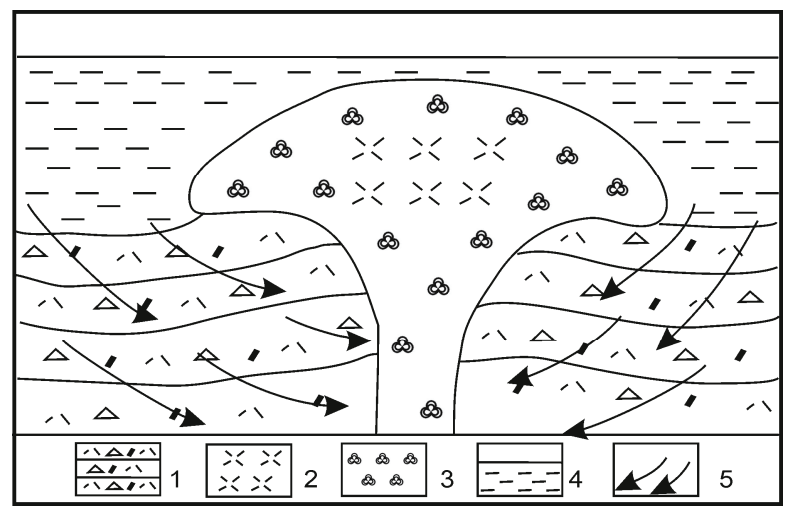

图 3 双层珍珠岩夹无斑或少斑流纹岩形成过程示意图

1 , 酸性玻璃质角砾凝灰岩; 2 , 流纹岩; 3 , 珍珠岩;

4, 地表水; 5 , 下渗地表水运动方向. 改自高恩忆(1986)

蚀变程度不均一, 含有不同阶段的蚀变产物, 甚至可 见块状原岩. 膨润土层需与其他水下喷发火山岩特 征相结合才能成为鉴定水下喷发火山岩的依据.

SSG2井2972 2977 m 段(图2)膨润土层以上部亚相 为主. $G R$ 曲线呈中振幅齿形, $R D$ 曲线正幅度差明显.

\section{4 氧化系数 $\left(\mathrm{Fe}_{2} \mathrm{O}_{3} / \mathrm{FeO}\right)$}

氧化系数 $\left(\mathrm{Fe}_{2} \mathrm{O}_{3} / \mathrm{FeO}\right)$ 是反应沉积环境氧化或还 原特征的化学指标之一. $\mathrm{Fe}_{2} \mathrm{O}_{3} / \mathrm{FeO}$ 值大于 1.5 为强氧 化环境, 1.0 1.5 为弱氧化环境, 0.8 1.0 为弱还原环境, 小于 0.8 为强还原环境(黄剑霞, 1987).

通过对研究区内水下喷发火山岩进行全岩分析, 结果表明该区水下喷发火山岩氧化比 $\left(\mathrm{Fe}_{2} \mathrm{O}_{3} / \mathrm{FeO}\right)$ 均 小于 0.8(图 4), 升深更 2、升深 2-12 和部分徐深 5 井 中水下喷发火山岩样品的氧化比低于 0.1 , 可以推测 该区火山岩在成岩过程受到水下还原环境的影响.

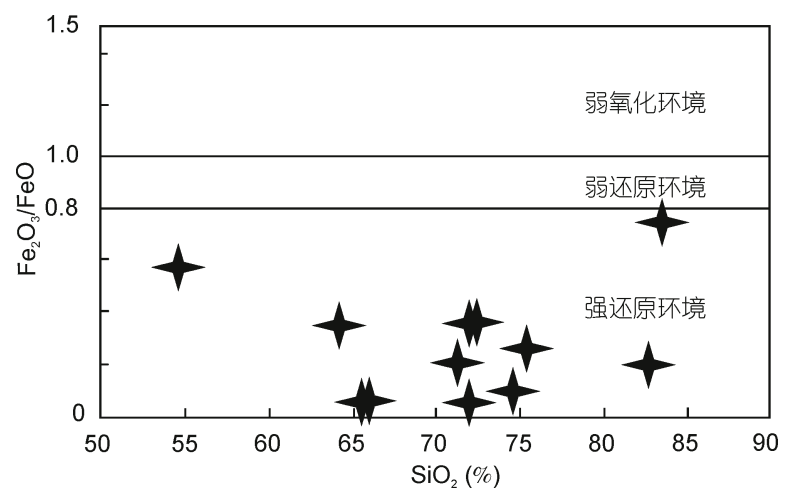

图 4 氧化系数分布特征

\section{3 松辽盆地徐家围子营城组陆相水下喷发 火山岩的分布范围}

通过对松辽盆地徐家围子岩芯和薄片的观察, 结合地震与测井资料和岩芯样品地球化学的测试结 果, 认为徐家围子断陷营城组具有一定厚度的水下 喷发火山岩. 具有水下喷发火山岩特征的钻井集中 分布在徐深 1 井区和徐深 21 井区东南部, 而在汪家 屯、升平和徐中地区的分布较为分散(图 5). 具有水 下喷发特征井段的厚度在 6 52 m, 平均厚度 $26.2 \mathrm{~m}$. 预测分布面积 $1331.36 \mathrm{~km}^{2}$.

徐深 1 4、徐深 2 和徐深 211 等井中存在有沉凝 灰岩与黑色泥岩互层的特征; 汪 905、徐深 5 和升深 更 2 等井中有双层珍珠岩夹无斑或少斑流纹岩的特 征, 升深更 2 井中珍珠岩脱玻化作用较强且含有膨润 土层. 研究区岩芯样品氧化系数 $\left(\mathrm{Fe}_{2} \mathrm{O}_{3} / \mathrm{FeO}\right)$ 普遍低 于 0.8 进一步证明徐家围子营城组火山活跃期, 地表 水体分布广泛.

\section{4 松辽盆地徐家围子营城组陆相水下喷发 火山岩的形成机制及对烃源岩的影响}

关于火山活动对烃源岩的影响前人已经做了大 量的工作和实验, 主要集中在火山岩中的某种单一 因素, 如某种金属元素或某种矿物对烃源岩生排烃 的影响(Mango, 1992; 万丛礼等, 2003; 翟庆龙, 2003), 而关于火山喷发和沉积环境对烃源岩的影响的研究 甚少. 陆相水下喷发火山岩按照喷发环境和沉积环 境的不同可以分为陆上喷发水下保存和水下喷发水 下保存两种. 高福红等(2009)曾提出水下喷发水下火 山岩对烃源岩的影响, 金强等(1998)建立了水下火山 喷发环境生油岩沉积模型, 但都是单一的考虑了火 山机构本身位于水下的情况, 即水下喷发水下保存 的情况，而未考虑到陆上喷发水下保存火山岩对烃 源岩的影响.

本文综合徐家围子营城组水下喷发火山岩的宏 观和微观特征及前人对其他地区水下喷发火山岩的 研究成果(张艳等, 2007; 王岗等, 2010; Niu 等, 2008; Head 和 Wilson, 2003; Mueller 和 Mortensen, 2002), 建 立了徐家围子水下火山喷发模式. 水下火山喷发火 山岩的产生有两种机制: 一种为陆上喷发水下保存, 即火山喷发于陆上, 喷出地表的火山碎屑和熔岩流 


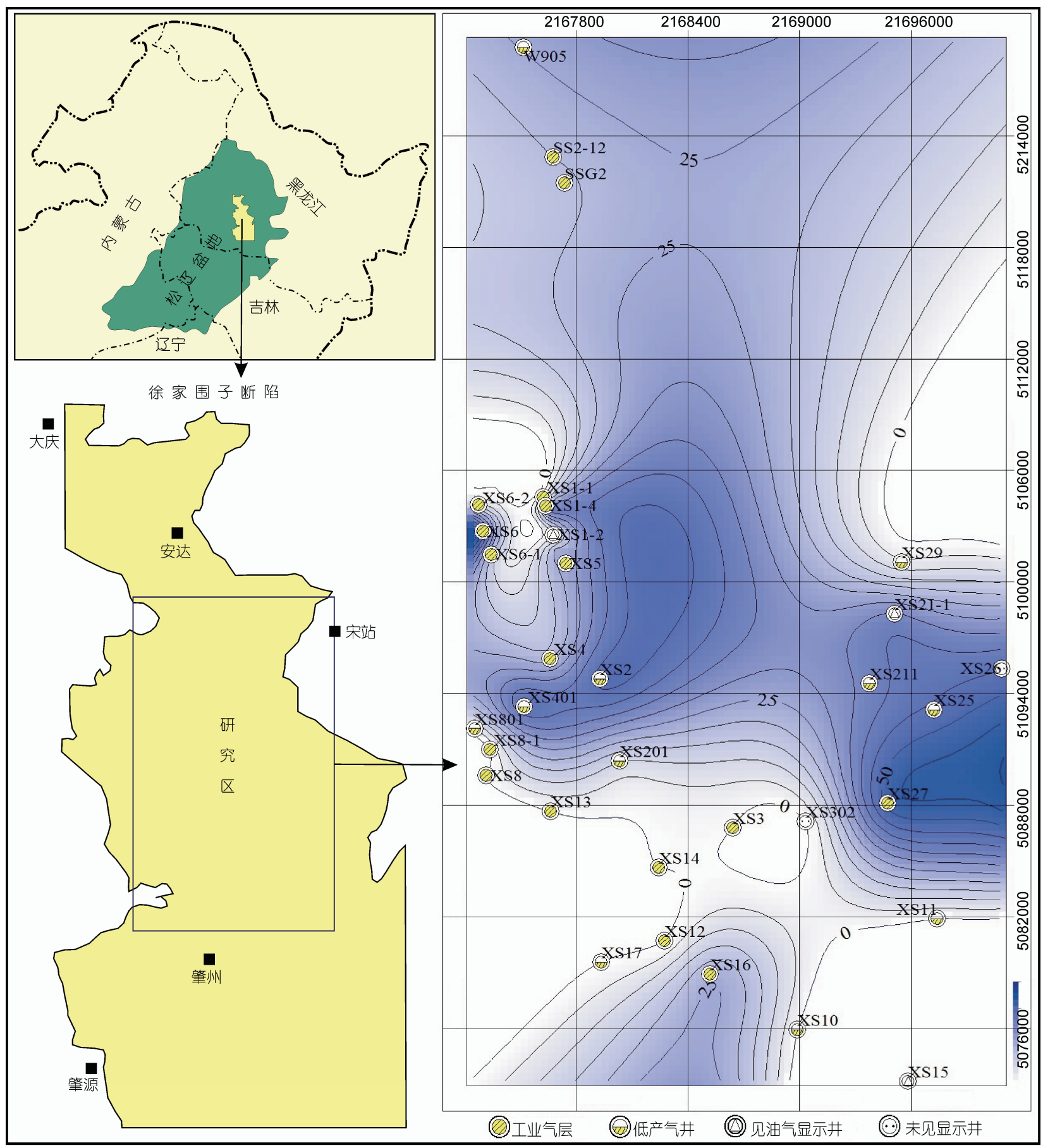

图 5 徐家围子断陷具有水下喷发特征火山岩厚度分布预测图

进入到火山机构附近的水体中沉积(图 6(a)), 火山碎 屑等物质缓慢沉积, 即可形成沉凝灰岩与泥岩互层 的现象, 而玻璃质火山物质在湖盆中水解便可形成 膨润土层. 另一种水下喷发水下保存, 即火山机构本
身潜于水下, 熔岩流和火山碎屑喷出地表后直接在 水下沉积(图 6(b)), 熔岩流进入水体后表面迅速淬火, 形成珍珠岩, 而熔岩流内部降温相对缓慢, 形成无斑 或少斑流纹岩. 


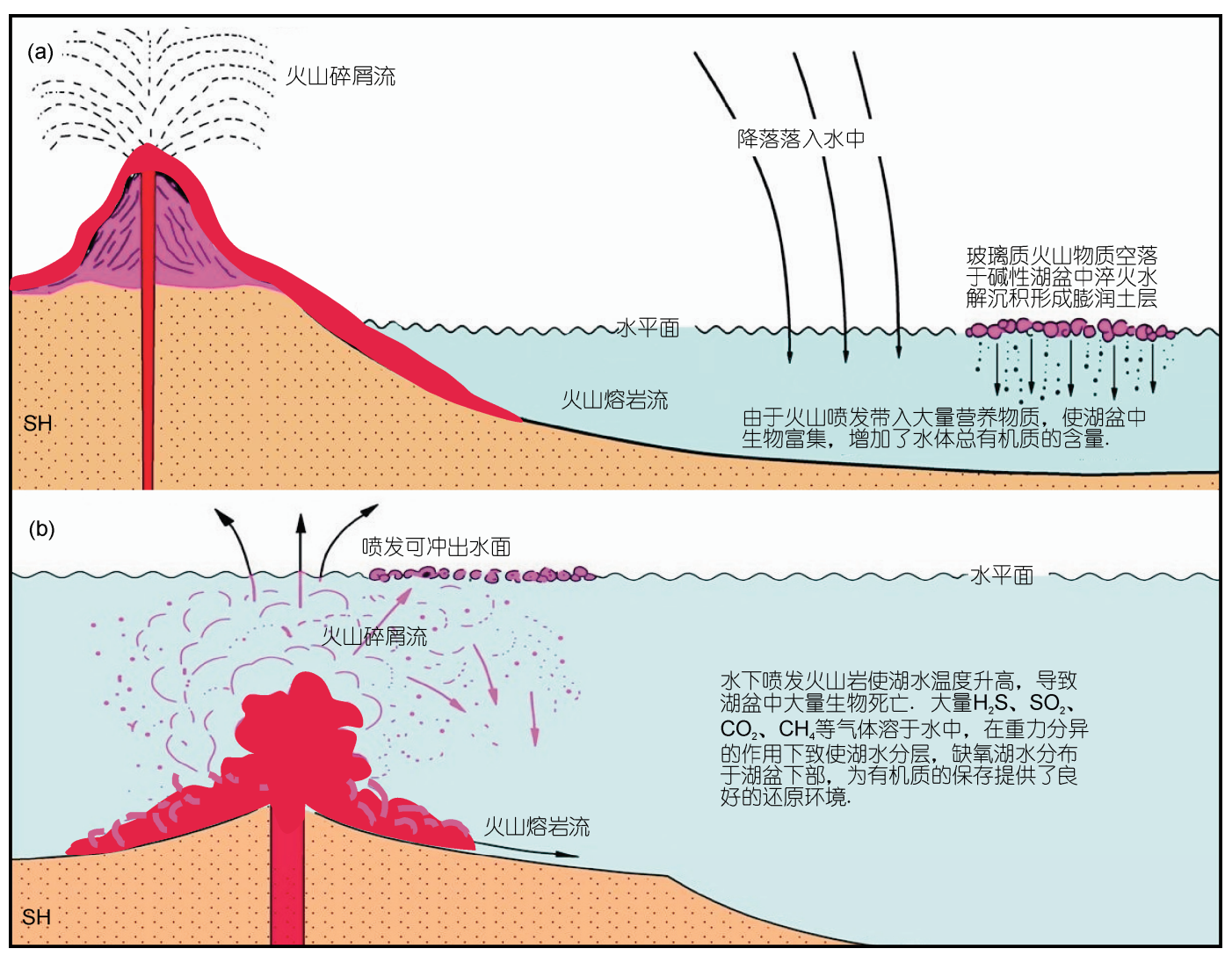

图 6 松辽盆地徐家围子营城组水下火山喷发及对烃源岩影响综合模式图

松辽盆地的主要河流和众多的溪流所携带的陆 源有机质和各种营养物质, 进入湖盆, 大大增加了湖 盆的营养程度, 为湖盆中生物繁殖创造了良好的生 成环境. 水下喷发火山岩使湖水温度升高, 导致湖盆 中大量生物死亡, 火山喷发过程中产生了大量 $\mathrm{H}_{2} \mathrm{~S}$, $\mathrm{SO}_{2}, \mathrm{CO}_{2}$ 和 $\mathrm{CH}_{4}$ 等气体, 与湖中的 $\mathrm{H}_{2} \mathrm{O}$ 和 $\mathrm{O}_{2}$ 等发生 反应, 在重力分异的作用下致使湖水分层, 缺氧湖水 分布于湖盆下部, 为有机质的保存提供了良好的还 原环境. 火山间歇期, 由于火山喷发带入大量营养物 质, 使湖盆中生物再次富集, 增加了水体总有机质的 含量(图 6).
按照陈建平等(1996)对泥岩 TOC 评价标准, 小 于 $0.5 \%$ 为差烃源岩, $0.5 \%$ 1.0\%为中等烃源岩, $1.0 \%$ $2.0 \%$ 为好烃源岩, 大于 $2.0 \%$ 为优质烃源岩. 徐家围 子单井营城组烃源岩平均有机碳含量在 $2.23 \%$ $2.706 \%$, 均大于 $2.0 \%$, 属优质烃源岩类(表 1). 证明 徐家围子水下喷发火山作用更有利于优质烃源岩的 形成.

\section{5 讨论}

松辽盆地徐家围子断陷营城组火山岩与烃源岩

表 1 松辽盆地徐家围子营城组泥岩有机地化对比

\begin{tabular}{|c|c|c|c|c|c|c|}
\hline 井位 & 地层 & 岩性 & ТOC\% & $\mathrm{S} 1+\mathrm{S} 2\left(\mathrm{mg} \mathrm{g}^{-1}\right)$ & $\mathrm{HI}\left(\mathrm{mg} \mathrm{g}^{-1}\right)$ & $T_{\max }\left({ }^{\circ} \mathrm{C}\right)$ \\
\hline XS1-2 & $\mathrm{K}_{1} y c$ & 泥岩 & 2.394 & 0.12 & 5 & 545 \\
\hline XS1-4 & $\mathrm{K}_{1} y c$ & 泥岩 & 2.335 & 0.334 & 11 & 542 \\
\hline XS22 & $\mathrm{K}_{1} y c$ & 泥岩岩屑 & 2.311 & 3 & 89 & 412 \\
\hline XS22 & $\mathrm{K}_{1} y c$ & 黑色泥岩 & 2.706 & 0.09 & 2.5 & 541 \\
\hline XS21-1 & $\mathrm{K}_{1} y c$ & 绿色泥岩 & 2.230 & 3.61 & 153 & 448 \\
\hline
\end{tabular}


存在着密切的空间关系, 不同喷发和沉积环境的火 山岩对附近的烃源岩有机质富集和成烃过程的影响 表现出了明显的特殊性和复杂性. 本文主要从宏观 的角度研究分析了松辽盆地徐家围子营城组水下喷 发火山岩所具有的特征及分布, 对于微观的矿物学, 岩石学等特征需要今后的研究中进一步阐述. 另外,
火山活动发生后, 湖盆中水体的成分、温度及酸碱度 的变化范围, 这些因素如何影响了烃源岩的形成过 程及质量等问题, 还缺少定量分析的证据. 只有科学 系统的区分各种模式下火山作用所引起影响，才能 掌握火山岩附近的烃源岩形成和演化的规律, 并最 终指导油气探勘和开发.

\section{参考文献}

陈建平, 黄第藩, 霍永录, 等. 1996. 酒东盆地异常流体压力带及与油气分布的关系. 中国科学 D 辑: 地球科学, 26: 9-15

陈建文, 王德发, 张晓东, 等. 2000, 松辽盆地徐家围子断陷营城组火山岩相和火山机构分析. 地学前缘, 7: 371-379

高恩忆. 1986. 辽西中生代火山岩中珍珠岩、沸石、膨润土成矿因素探讨. 辽宁地质, 1: 35-46

高福红, 高红梅, 赵否. 2009. 火山喷发活动对烃源岩的影响: 以拉布达林盆地上库力组为例. 岩石学报, 25: 2671-2678

胡志宪. 1987. 内蒙古市榆林珍珠岩、沸石岩矿床成因及控矿因素探讨. 四川建材学院学报, 4: 47-60

黄剑霞. 1987. 厦门港湾氧化-还原沉积环境的划分. 台湾海峡, 6: 27-32

姜福芝, 王玉往. 2005. 海相火山岩与金属矿床. 北京: 治金工业出版社. 248

金强, 熊寿生, 卢培德. 1998. 中国断陷盆地主要生油岩中的火山活动及其意义. 地质评论, 44: 136-141

牛志军, 徐安武, 王建雄, 等. 2008. 青海南部二叠纪罗甸期火山岛沉积相模式及对簙类动物群分布的制约. 中国科学 D 辑: 地球科学, 38 : $145-156$

万从礼，金强，翟庆龙. 2003. 东营凹陷滨南地区水下火山喷溢对烃源岩形成及生烃演化的作用. 石油大学学报(自然科学版), 27: 17-21

王岗, 李文厚, 林潼, 等. 2010. 陆上、水下喷发成因火山岩储层发育特征和成藏控制因素对比分析一以三塘湖盆地石炭系火山岩油藏 为例. 地质科学, 45: 1088-1097

王玲, 靳久强, 张研. 2009. 松辽盆地徐家围子断陷营城组一三段火山喷发期次划分及意义. 中国石油勘探, 2: 6-13

翟庆龙. 2003. 火山热液活动对烃源岩生排烃的作用——东营凹陷西部沙三段为例. 油气地质与采收率, 10:11-13

张艳, 舒萍, 王璞君, 等. 2007. 陆上与水下喷发火山岩的区别及其对储层的影响—以松辽盆地营城组为例. 吉林大学学报(地球科学版), 37: 1259-1265

张耀夫, 陈鹤年, 巫全淮, 等. 1990. 东南沿海珍珠岩矿床及其成因. 中国地质科学院南京地质矿产研究所所刊, 11: 75-90

Davis B K, McPhie J. 1996. Spherulites, quench fractures and relict perlite in a Late Devonian rhyolite dyke, Queensland, Australia. J Volcanol Geotherm Res, 71: 1-11

Embley R W, Chadwick W W, Baker E T, et al. 2006. Long-term eruptive activity at a submarine arc volcano. Nature, 441: 494-497

Head J W, Wilson L. 2003. Deep submarine pyroclastic eruptions: Theory and predicted landforms and deposits. J Volcanol Geotherm Res, 121: $155-193$

Lafrance B, Mueller W U, Daigneault R, et al. 2000. Evolution of a submerged composite arc volcano volcanologyand geochemistry of the Normetal volcaniccomplex, Abitibi greenstone belt, Que’bec, Canada. Precambrian Res, 101: 277-311

Mango F D. 1992. Transition metal catalysis in the generation of petroleum and natural gas. Geochim Cosmochim Acta, 56: 535-555

Mueller W U, Mortensen J K. 2002. Age constraints and characteristics of subaqueous volcanic construction, the Archean Hunter Mine Group, Abitibi greenstone belt. Precambrian Res, 115: 119-152

Palinkas L A, Bermanec V, Sostaric S B, et al. 2008. Volcanic facies analysis of a subaqueous basalt lava-flow complex at Hruskovec, NW Croatia: Evidence of advanced rifting in the Tethyan domain. J Volcanol Geotherm Res, 178: 644-656

Parfitt E A, Gregg T K P, Smith D K. 2002. A comparison between subaerial and submarine eruptions at Kilauea Volcano, Hawaii: Implications for the thermal vibility of later feeder dikes. J Volcanol Geotherm Res, 113: 213-242

Seghedi I. 2011. Permian rhyolitic volcanism, changing from subaqueous to subaerial in post-Variscan intra-continental Sirinia Basin (SW Romania-Eastern Europe). J Volcanol Geoth Res, 201: 312-324

Yamaqishi H. 1990. Review of 1980's literatures on subaqueous volcanic rocks and several examples of subaqueous lavas (in Japanese). Earth Sci, 4: 295-307 